\title{
The effect of government expenditures on economic growth. The case of Albania
}

\author{
Lorena Çakerri \\ Migena Petanaj \\ Oltiana Muharremi \\ University of Vlora,Ismail Qemali,Faculty of Economy. \\ lorena.cakerri@gmail.com \\ migenapetanaj@hotmail.com \\ olta.muharremi@gmail.com
}

\begin{abstract}
One of the main issues of economic policy and government is to ensure a sustainable economic growth of a country. Economic growth has been at the center of every government in place since at least year 2000. Though for this teen-year, growth values were satisfactory in Albania, the macroeconomic situation changed in 2009, when appeared the elements of the global crisis. Economic global crisis has awakened interest in the case of fiscal policy.Fiscal policy and monetary policy as well, are two basci components of state economic policy which are used for macroeconomic purposes:influence of gross domestic product, the level of enmployment, income and price level. The two main instruments of fiscal policy are government expenditures and taxes. Government expenditures are considered as the most powerful weapon available to fiscal policy makers, especially in developing countries such as Albania. During the last century, governments have spent more and more in relation to their national income. This increase in government spending can be explained by the impact that this variable can have on the economic growth of a country? In fact, about the connection between the government spending and the economic growth of a country various studies seem full of contradictions. This conflict is explained by changes in terms of definitions and from the differencies of the various countries included in these studies. The objective of this study is to give an appropriate answer to the question: Can government spending have the potential to impact and stimulate economic growth? How the changes of the size of the fiscal policy instruments have affected indicators of economic growth in Albania? This article will focus on the role that the fiscal policy has on economic growth, especially in our country, reviewing economic growth theories, debates about the effectiveness of fiscal policy, and active fiscal policy. Finally some suggestions for the future addressing the government expenditures towards priority sectors.
\end{abstract}

Keywords: fiscal policy, government spending ,economic growth

\section{Introduction}

One of the main objectives of the fiscal policy is that public spending can provide a stable economic growth in many programs . The goal of public finances is the promotion of sustainable economic growth. Public expenditures have played an important role in shaping the physical and human capital over a period of time. Appropriate public spending can be effective in promoting economic growth, even in the short term. Therefore, the effect of public spending on growth can be a complete indicator of the productivity of public spending. In the 1970s and 1980s, most developing countries were experiencing serious fiscal imbalance. This is manifested in the rapid growth of public expenditures that exceeded revenues. Resulting fiscal crisis are found to be unstable in all affected countries. Consequently, these countries demanded the creation of fiscal programs aimed at reducing the unsustainable fiscal deficits and ensuring economic growth. Two options are available to achieve this first objective. First option is to increase income in order to make it possible to reduce the fiscal deficit. But, given the difficulties of raising tax revenues in the short term, the second option,spending-reduction seems more accessible to correct fiscal deficits. While such reductions are necessary, must be considered the implications of each of the components of public expenditure on economic growth indicators, taking care that this may result in unacceptable economic cost and social.

Many developing countries, including Albania are applying the substantial macroeconomic changes. Consequently it is not yet clear how these programs will affect the index of public spending and yet more economic growth and poverty reduction. Therefore it is important monitoring levels and trends in composition of government spending, and to assess the causes of change over time. This is even more important analyzing the relative contribution of different costs of production growth and poverty reduction, as this will provide important information for more efficient targeting of these financial resources.

Theoretical relationship between government spending and economic growth will be addressed in this paper. There are two main theories in economics about the relationship between government spending and economic growth that have 
ISSN 2411-9563 (Print) ISSN 2312-8429 (Online)
European Journal of Social Sciences Education and Research
September-December 2014

Volume 1, Issue 2

different views about this connection. While Keynesian macroeconomic theory assumes that increasing government spending will have a tendency to run us into higher aggregate demand and ensuring a rapid increase of economic growth . Wagner's theory is oriented toward an opposite opinion. The latter claims that national income growth causes more costs to government. The question whether the increase in public spending growth will bring policymakers divided into two separate camps theoretical, with preference for small government or big government. Economic theories would suggest that in some cases lower levels of government spending will cause economic growth, while in other cases the high levels of government spending would be more preferable. From an empirical perspective becomes more confusing evidence generated as a number of studies favoring one or the other approach. The main focus of this paper will be concisely reviewing the existing empirical literature in order to discuss the relationship between government expenditures and economic growth. Some times a big government and the increase is conducive to better economic performance. In fact, in most cases enlarge the size of government will lead to higher levels of income and improve economic growth, if the expenditures are addressed to productive sectors.

\section{Literature.}

\section{The evidence pointing to a negative relationship}

There are many empirical studies that support the negative relationship between public spending. Barro (1991) in a study of 98 countries for a period spanning from 1960 to 1985, using the average annual growth rates in real GDP per capita and the ratio of real government consumption to real GDP concluded that the link between growth economic and consumption is negative and significant. Jong-Wha Lee (1995) provided further evidence for the negative relationship between consumption of government and economic growth. More specifically, using an endogenous growth model for an open economy, it is found that government consumption and economic output was associated with slower growth. Starting with the U.S. economy, Knoop (1999) using time series data for the years 1970-1995 concluded that a reduction in the size of government will have a negative impact on economic growth and welfare. Estimates obtained by Fölster and Henrekson $(1999,2001)$ while conducting a panel study in a sample of rich countries during the period 1970-1995 gave support to the idea that large public expenditures negatively affect growth. In another empirical study, Ghura (1995), shows the existence of a negative relationship between government consumption and economic growth. During his investigation turned out that the fact that countries with higher rates of growth have experienced higher ratios of investment, export volume growth, higher life expectancy of life at birth, low inflation rates, and standard deviations low inflation, but it does not necessarily mean better terms of trade outcome.

In an attempt to investigate the relationship between government size and the unemployment rate Burton (1999) using a structural model error correction for twenty OECD countries for the period 1970-1999, found that the size of government, measured as total government expenditure as a percentage of GDP, has played a significant role in the sustainable level of unemployment.

Using collected data for 113 countries, Grier and Tullock (1989) have investigated the empirical rules of postwar economic growth. Among other results, they found that government consumption is negatively correlated with economic growth. The same study also Konstantinos Alexiou emerged that political repression is negatively correlated with the increase in Africa and Central and South America.

Guseh (1997) in a study on the effects of government size on economic growth rate using Ols estimation , using timeseries data for the period $1960-1985$ to 59 countries with average incomes in developing countries provide evidence suggests that increased government size has a negative impact on economic growth, but the negative effects are three times greater in non-democratic socialist systems than democratic systems market. Further assessments provided by Engen and Skinner (1992) for 107 countries over the period 1970 to 1985, suggested that a balanced-budget increase in government spending and taxation is predicted to reduce output growth, while Carlstrom and Gokhale (1991) reported simulations results according to which the increase in government spending causes a long-term decline in manufacturing.

Adopting a Granger casuality approach , Conte and Darr (1988), have investigated the causal dimensions between public sector growth and real growth rates for OECD countries. Special emphasis was placed on the effects on economic growth as a result of increased government resulting from macroeconomic policy. Based on the evidence, the increase in government spending has had mixed effects on economic growth rates, positive and negative for some countries to others. For most OECD economies, however, there is no significant impact of the government's perceived growth rate of real economic growth.

The many reasons for the negative relationship between government size and economic growth are: 
ISSN 2411-9563 (Print) ISSN 2312-8429 (Online)
European Journal of Social Sciences Education and Research
September-December 2014

Volume 1, Issue 2

- The cost of extraction. Government spending requires costly financing choices. The government can not spend money without taking money from someone. All options used to finance government spending will have negative consequences costly.

- The displacement cost. Government spending displace private sector activity. Every dollar the government spends a dollar means less productive sector of the economy. This reduces economic growth while forces guide the allocation of resources in the private sector.

- Cost of negative multiplier. Finance government expenditures harmful interference. Part of the budget is used to finance activities that generate overtly negative effects on economic activity. For example, many regulatory agencies have relatively small budgets, but they impose large costs on the productive sector of the economy.

- The behavioral subsidy cost. Encourage government spending destructive choices. Many government programs subsidize economically undesirable decisions. Welfare encourages people to choose leisure. Unemployment insurance programs provide an incentive to remain unemployed.

- The behavioral penalty cost. Discourage productive government spending choices. Government programs often discourage desirable economic decisions. Saving is important to help provide capital for new investments, but the incentive to save has been undermined by government programs that subsidize retirement, housing, and education.

- The cost of market distortion. Government spending inhibit the allocation of resources. Prices in competitive markets stipulate a process that ensures the most efficient allocation of resources. However, in both areas, health care and education, government subsidies to reduce out of pocket costs have created a problem of "third party payment".

- The inefficiency cost. Government spending is one of the least effective ways to deliver services. The government directly provides many services and activities such as education, airports, and postal operations. However, there is ample evidence that the private sector can provide these important services at the highest quality and lower costs.

- The stagnation cost. Government spending inhibit innovation. Because of competition and the desire to increase income and assets, individuals and entities in the private sector constantly searching for new options and opportunities. Government programs, however, are inherently inflexible.

\section{Evidence pointing toward a positive relationship}

Contrary to the negative association between government spending and economic growth established by the aforementioned studies a growing body of literature attempts to redress the balance by suggesting that the state can actually, through implementing appropriate policies, nurture productive activities and reduce unproductive ones (see for instance Amsden, 1989; Epstein and Gintis 1995, Burton 1991). More specifically, Kelly (1997) by exploring the effects of public expenditures on growth among 73 countries over the period 1970-1989 found that the crowding-out and rent-seeking concerns might have been overstated in the literature. According to the evidence obtained the contributions of public investment and social expenditures to growth is rather significant. Further more, Alexiou (2007) in a study for the Greek economy, after disaggregating government spending, reported evidence on the basis of which there is a positive association between the growth in the components of government spending and GDP growth. Aschauer (1990) also documented a positive and significant relationship between government spending and the level of output.

Despite the fact that even the crowding-out literature, has recognized a limited but significant effect of public investment on growth, social programmes have been rendered unproductive, with the exception of education. Thereby, most of the studies conducted have exclusively focused on education as a significant factor which impacts growth through its effect on human capital (Barro, 1991; Roubini and Sala-I-Martin, 1991; Birdsall, Ross and Sabot 1995).

It becomes apparent that the relationship between government spending and economic growth is far from clear. Two key points however can be made when reviewing the empirical studies: empirical results are specification sensitive and the relationship between government spending and economic growth is generally negative when connection is expressed as percent of GDP and is generally positive when expressed as an annual percentage change.

\section{Public spending}

\section{Meaning and essence of public expenditure}

There are some essential functions that governments perform in many countries, and that can not be done by the private sector, for example, national defense, security and territorial integrity, ensuring social welfare, the establishment of a legal framework, development of industries and infrastructure etc.. These functions spend considerable public funds. Public expenditures are closely related to the existence of the state and his functions. With the enforcement of the role of the state have increased the costs of public spending. Two features of public spending are: 
1-they serve to meet the collective needs and interests for public 2 - and they are spent money

So public spending are money expenditures that makes the state and other entities for meeting legal and political needs for collective and public interests.

In developing countries, public expenditure policies deal with accelerating economic growth, development and employment opportunities to play an important role in reducing the level of poverty and income distribution. We should make a distinction between public expenditure and revenue, because the first should be determined the public spending to finance the public needs in order to determine after public revenues, as a funding source of public spending.

Public expenditures used to meet certain social needs, different in scope and structure as:

a. the general public needs (state administration needs, keeping foreign embassies in the world, armada financing, granting of subsidies) b. joint and collective needs (the needs of education, culture, science, health, security service pension and disabled) c. economic nature needs of the state (state intervention in the economy, in international economic relations, investment in infrastructure etc.)

\section{The volume of public expenditure}

In all countries there is the tendency of increasing public spending permanently. Some theorists explain this fact therefore increasing public spending with economic growth of the country and others in political causes. Setting minimum and maximum limit of government expenditure is studied by many theorists who claimed that classical public spending should be as low and moving in the border $15 \%-25 \%$ of national income. While financial modern theorists appoint not limit public spending and they put it in the center of injuring effects that cause public spending, but they also put a limit on public spending especially unproductive public spending in cases where all requirements is possible. But of course the limitation of public spending depends on the economic development of the country and the level of national income. Causes of increased public spending according to Gaston Jeze are divided into two groups: apparently causes (formal) by Jeze which are: a) reduction of the purchasing power of money, i.e as far as the value of money falls, the more increased public expenditure b) technical changes in state budgeting c) changes in the size of the state, the growth of the state territory and population is a formal cause of increasing formal public spending. Real causes by Jeze splits in: a) the causes of economic nature. These reasons are related primarily to the economic development of the country because economic development creates new public needs that the state must meet with its own budget in the cultural sphere as well as in the social sphere, while the second are related to competition in foreign markets where the state should spend more because of export premiums, price dumping, etc. b) the causes of political nature. These reasons can be divided into internal and external. In internal causes can be introduced forms of government, regulation democratic country which influences the growth of public spending because increases influence in the broader measures of education policy and the treatment free of charge and in social contributions. External causes are toughened world political situations which leads to policy strengthening of weapons, military bases increase ,duration of military service etc.. C) financial nature causes. Within these causes should be noted that the payment of the public debt increases public spending and mismanagement of public funds during the budget surplus.

\section{The effects of public spending}

Public expenditures today are a very important instrument which act in the economic, political and social development of a country. In this sense we find two concepts:

Neutral effect of public spending is bourgeois concept of classical theory which is based on the exclusion of the state in social and Economic development of the country, and in public expense as small as possible.

Active effect is based on the impact of public spending and social-economic sphere. These effects are many, we are constantly expanding and achieving economic structure reflected in the growth of social production. Through public revenues the state receives from the economy and affects the population actively in production and redistribution turning them in the form of public spending . Government expenditures change economic and social structure of the state.

\section{Total government expenditures in the years 2000-2011 in Albania.}

Total government expenditures are non-refundable payment to the realization that government performs its functions through the purchase of goods, services, transfers or interest payments. Distinguished in two main groups: current expenses and capital expenditures. Current expenditures include payments for services and consumable items for less than a year, debt interest and various subsidies. While capital expenditures included payments for items and services with shelf over a year. 
As can be seen from the graph 1 and 2, there is a steady increase in total expenditures of the State Budget. These rates are higher especially after 2006 , to the maximum in 2008 , where spending increased by $23 \%$ versus 2007 . Among the main factors that contributed to such high growth were investments, which recorded a level 37 billion higher than a year ago. The year 2009 stands out for a considerable expense, but this time make the difference recurrent expenditure, 35 billion more than in 2008 . Interestingly spending contraction suffered in 2010 , decreasing by $4.8 \%$ which occupy the main place investments with a decline of 30 billion ALL or $30 \%$ compared to 2009 .

\section{A structure of budget expenditures}

The structure of budget expenditures ratio means that current and capital account expenses against total expenditure

As can be seen from the graph 3 it is noted that until 2005, the main item of expenditure were those current, while after this year, the trend starts to change, always giving more priority to capital expenditures, for the necessity to sustain economic growth. In 2008 and 2009, capital expenditures occupy higher weights by $27 \%$ and $25 \%$, years that coincide with the financing of the project "Building Rreshen road."

\section{Capital Expenditures 2000-2011}

Understood capital cost payments for items and services on a year long use. These include payments for items with the benefit of long-term use, fixed capital assets and payments for replacement of fixed assets destroyed.

The graph 4 gives a clear idea of priority investments that have taken over the years. Their rise steadily, mainly from 2005 is made possible thanks to a high performance of the fiscal sector income, income from the privatization of some important facilities and support from foreign funding. 2008 and 2009 mark the highest figures, which actually matched the main financing the project "Building Rreshen road."

\section{Investment Financing Structure}

There is a constant behavior towards the funding method. However, since 2004 highlights a growing amount of domestic financing, which culminates in 2009. During this year, funded by domestic investment amounted to 81 billion, with 40 billion or nearly $50 \%$ of the funds have served to finance the project "Building Rreshen road." External financing also presented significant fluctuations. It culminates in 2008 with 43.6 billion, $78.8 \%$ of which served to finance the project "Building Rreshen road." Support the project with foreign capital has given proper breathing to the business. This is very clear in the graph 5.

\section{Allocation of budget expenditures for 2012 by functions.}

As can be seen from graph 6 social protection is $30 \%$; General public services $20 \%$; education $12 \%$; economic issues $12 \%$; Health $10 \%$; housing and community amenities $6 \%$; public order and safety $6 \%$; protection $3 \%$; recreation, culture and religious affairs $1 \%$

Economic issues, including the construction of transport infrastructure received 44 billion or 12 percent of total expenditure and at the same level that the Health sector was spent Arsimit.Për one in every ten leks, or 10 percent. Total expenditure on health was 36.5 billion.

Environmental protection, including costs for land clearing, sewage processing and rehabilitation of contaminated areas is the function of government to lower costs in Albania. During 2012, it was planned that this function consumed 1.1 billion while actual expenditures were only 472 million or 0.1 percent of total expenses.

Recreation, Culture and Religious Affairs function seems to have been most favored by the government for 2012. Initial plan was to spent 2.8 billion while the final costs were 70 percent higher, or 4.7 billion. But this function accounts for less than 1 percent of all budget expenditures.

Public order and safety, including the costs of police, judiciary, prisons and fire protection, was 21.1 billion for 2012, slightly higher than the beginning of the plan year. These costs account for 6 percent of total budget expenditures.

\section{Budgetary Expenditures Albania Compared with countries Region}

In the case of Albania, budget expenditures for 2009 were approximately 379 billion or $33 \%$ of GDP.

Compared with the regional countries, Albania is as follows:

As can be seen from the graph 7, Albania expenditures to GDP are lowest in the region. Meanwhile ranked in first place: Greece (50.4\%) followed by Bosnia and Herzegovina (50\%), Montenegro (47\%), Serbia (44\%), Croatia (42\%), Turkey (37\%), Macedonia (33\%) and Kosovo (31\%). By analyzing the time, noted that the country with the greatest 
ISSN 2411-9563 (Print) ISSN 2312-8429 (Online)
European Journal of Social Sciences Education and Research
September-December 2014

Volume 1, Issue 2

reduction of budget expenditures over the last decade is Bosnia and Herzegovina, while the country with the largest increase is Kosovo ..

\section{Economic growth in Albania}

One of the fundamental issues of economic policy and the government is to ensure a sustainable economic growth. Economic growth has been at the center of any government and political force in the country since at least 2000. Though this decade growth values were satisfactory macroeconomic situation changed in the last five years. Adverse effects appeared mainly in 2009, the year in which the elements of global crisis appeared. Macroeconomic developments during the year were formed in the context of the global financial crisis and the real economy. The only positive element was that the Albanian economy was affected less by the crisis than other countries in Eastern Europe, due to a lower degree of openness to the world economy in comparison with these countries. According to the Bank of Albania, in the international scenario, the country's economic growth slowed as a result of the slowdown in domestic demand and external, in the presence of liquidity tightening and reduction of foreign currency inflows. Aggregate demand as a source of sustained growth reduction as a result of reducing consumption, private investment and export demand. Also there has been a reduction of imports, especially of capital goods, which together with the reduction of remittances and limiting lending directly affected private investment. Also the growth of government spending in the first half of the year, the depreciation of the lek, rising deficits contributed to curbing private investment. Due to the effects of the global crisis created a climate of insecurity which led to reduced consumption and increase savings instead. The same situation appears unfavorable in 2010. Economic growth has remained almost the same values with a year ago, far from optimistic forecasts. Even for the period 2011 - 2013 values of economic growth have not been any significant improvement with values closer to its histoike 5-6 percent. Greek crisis which continues for months can be a real threat for the Albanian economy for two reasons: the large number of emigrants there and large Greek businesses in Albania, where the most important are mobile telephony and banking sector, but other sectors others such as construction, trade, tourism, etc.. . The effect is directly related to investment, where Greece is one of the leading investors and a decrease in investment would impact negatively on economic growth, employment, poverty etc. Besides the negative effect of the crisis many economists believe that the current sources of economic growth are consumed. Remittances can not be considered more important and a source of continuous economic growth in Albania. Since 2006, feels a downward trend which is expected to reflect a loss in the amount budgeted $1 / 2$ - 1 percent of GDP per year for the period (2006-2010). So in the decade effect of remittances will always be smaller. Also donations, aid and soft loans are minimized. Other sources seem to exhaustion. In these conditions, policies should be directed at sectoral levels, such as agriculture, energy, industry, diversification of products, increased competition, the application of advanced technologies, harmonization of educational policies to the needs of the economy and businesses, including the wider population benefits from economic growth. In recent years, successive Albanian governments have focused on the political and economic criteria required for EU integration, often at the expense of social issues of poverty .. Despite a slight increase, Albania in 2011 came from the place it occupied among countries with high human development, being ranked 70th out of 167 countries. The country's poverty rate remains high, and is further combined with significant regional disparities and urban / rural. GDP purchasing power parity was estimated to be only $28 \%$ of the average EU-27. A United Nations study shows that Tirana, the capital, has a 0.75 index GDP and $83 \%$ enrollment rate in education, compared with an index of $0.655 \mathrm{GDP}$ and $65 \%$ enrollment rate in education in mountainous areas. In addition, the country's Gini coefficient shows that economic inequality has increased; Gini coefficient from 20 to 34.5 Albania has overcome in the last decade. Agriculture, the only source of income for rural areas, excluding remittances, occupies less than one-fifth of GDP, although the sector claims nearly half the country's workforce. Poor equipment, property rights outstanding, and small plots of land contributing to the inefficiency of the agricultural sector.

As can be seen in graph 8 Albania has continued to record positive growth during the review period. After an average of $3.3 \%$ of GDP in 2009 to 2011 , are noted signs of a rapid slowdown, especially in the first half of 2012, with a production increase of $0.2 \%$. However, the economy has recovered to some extent, registering GDP growth of $0.6 \%$ in 2012, according to the European Bank for Reconstruction and Development. (EBRD). Major determinants of economic slowdown are: a contraction in demand from key external partners to Albania, Greece and Italy, weak domestic demand and business confidence, driven mainly by the weakening of credit growth and decline in remittances; and the difficulties faced by companies in meeting government bills and VAT refunds. Inflation fell below a target range of $3 \%,(-1+1 \%)$ in the first months of 2012, prompting the central bank to lower the interest rate on the lowest level in history, 4\%. Yet economists fear that a worsening of the euro-crisis world will further affect the fragility of the Albanian market rate. The budget balance has continued to shrink, while tax revenue declined due to weak loan growth and business confidence.

External financial crises, especially the Greek debt crisis, have the potential to seriously put Albania's economic situation at risk. Greece is home to more than half of the 700,000 Albanian immigrants, who provide $35 \%$ of total remittances 
ISSN 2411-9563 (Print) ISSN 2312-8429 (Online)
European Journal of Social Sciences Education and Research
September-December 2014

Volume 1, Issue 2

and thus a significant part of the GDP of the country. Besides that remittances are falling, the Greek crisis could affect unemployment rates, because many immigrants are facing serious difficulties in the Greek labor market and returning to Albania. According to the European Bank for Reconstruction and Development (EBRD) 2012 Report to Place "GDP growth in 2012 and 2013 will likely be below levels that have been seen in recent years, and weaknesses will remain high as long as countries neighboring euro zone will remain in trouble. General contraction in demand from Western markets has seriously deteriorated the balance of foreign trade of the country. Problems such as high public debt and a high deficit in the current account, when combined with plans ambitious spending, low levels of investment and remittances, poses serious challenges in the near future.

\section{Conclusions}

One of the fundamental questions raised by many economists is why different countries are characterized by different rates of economic growth? Literature suggests that there is a large number of factors that explain the differences between countries, among which are: human and capital resources, the level of macroeconomic stability, institutional development, education, the effectiveness of the legal system, international trade, and legal and other ethnic diversity. One of the most important factors, which are given a special attention is the role and size of public spending, where his positive link between economic growth is a undisputed fact .So, the role and size of public spending is considered as an element key development and economic growth. One of the challenges of fiscal policy faced in transition, is the stabilization, but without impeding the necessary fiscal restructuring. Stabilizing itself requires the improved fiscal instruments. Government spending also have their own problems towards resistance, which has been periodically. Addressing priority sector expenditure against is an important issue, but not the only one. The way they are used and where mostly addressed towards capital investment and recurrent expenditure is quite difficult to judge. Government should be able to limit the level of spending that is available to use in the most possible efficient manner. According to research achievements in this area exist but there are still challenges for the future. At the same positions is presented management expenses which are paid due importance especially after 2000 , where improvements have been made mainly in the formulation, adoption and implementation of the budget, to create continuity and stability in public decision making. It would be very appropriate for Albania to undertake fiscal reform in consultation with international guest organizations to enter into a public finance crisis in conditions when other circumstances are not favorable. The large difference of recurrent and capital expenditure makes you realize that most of these expenditures have gone to unproductive investments. There are not too many empirical studies regarding the effect of economic growth versus expenses which have a wide variance of results. This variance is explained by the variables considered, the variables conditioner or initial conditions, selected countries which can be developed economies, or developing or heterogeneous choice of countries included in the study. Unlike the total spending, spending on sectors like education, health, infrastructure development and research expenses have a positive effect on economic growth from a theoretical standpoint as well as from the empirical perspective. One of the conclusions of this paper is that government spending positively affect economic growth, unlike reportedly mostly in theory. This conclusion is because our country is a transition country where the public sector is very important in the progress of economic reform, private sector development, etc.. Productive expenditures also positively affect economic growth, as predicted in theory.

Besides the fiscal variables, private sector investment-which may have been positively influenced by government spending, particularly on infrastructure, as documented in other studies - appears to have been an important engine of growth in these countries. This result is particularly relevant for policymakers as it implies that, when considered

jointly with the bulk of economic expenditures, education and health have a positive impact on growth, both in the short and the medium-term. The composition of public spending evolves as growth dynamics unfold to focus on those productive sectors/activities that are more conducive to growth. In this respect, policy makers should plan and implement jointly social and economic spending, as part of an integrated strategy, and attempt to gradually reduce allocations to unproductive spending - despite the fact that distinguishing a priori between productive and unproductive outlays may not always be easy. Our overall conclusion therefore is that public spending can be a significant determinant of growth, if countries are able to devote a significant fraction of these expenditures to productive uses. Therefore, the government should increase their public expenditure to encourage economic growth. Government should ensure that capital expenditure and recurrent expenditure are properly managed in a manner that it will raise the nation's production capacity. Government should direct its expenditure towards the productive sectors like education as it would reduce the cost of doing business as well as raise the standard living of poor ones in the country. 


\section{References}

[1] Alexiou, C. (2007) . Unraveling the 'mystery' between public expenditure and growth: empirical

[2] evidence from Greece. International journal of economics 1(1): 21-31.

[3] Alexiou, C. and Anastasiadis, G. (2008) . FDI and Ffnancial restructuring in the SEE." Working paper, South Eastern

[4] European Research Centre, (SEERC), University of Sheffield.

[5] Afonso Antonio, Furceri Davide (2008), Government size, Composition, volatility and economic growth, ECB working

[6] paper series, No 849, January;

[7] Afonso Antonio, Alegre Juan Gonzales (2008), Economic growth and budgetary components, A panel assessment for

[8] the EU, ECB working paper series, No 848, January;

[9] Amsden, A. (1989) Asia's next giant. New York: Oxford university press.

[10] Aschauer, A.D. (1990) "Is government spending stimulative?" Contemporary policy issues 8: 30-45.

[11] Barro Robert J. (1988), Government spending in a simple model of endogenous growth, NBER Working Paper Series,

[12] WP No. 2588

[13] Barro Robert J. (1991), Economic Growth in a cross section of countries NBER working papers 3120, National Bureau

[14] of Economic Research, Inc.

[15] Birdsall, N., D. Ross and R. Sabot (1995) . Inequality and growth reconsidered." World Bank Economic Review 9:

[16] 477-508

[17] Blanca Moreno-Dodson, Worldbank,How public spending can help you grow?An empirical analysis for developing

[18] countries 2010

[19] Boeri, T. and Flinn, C. (1999) .Returns to mobility in the transition to a market economy." Journal of comparative

[20] economics 27(1): 4-32.

[21] Burton, A. (1999) "The effect of government size on the unemployment rate." Public choice 99: 3-4.

[22] Carlstrom, C. and J. Gokhale (1991) . Government consumption, taxation, and economic activity. Federal Reserve

[23] Bank of Cleveland Economic Review 3rd Quarter: 28-45.

[24] Conte, M.A. and A.F. Darrat (1988) . Economic growth and the expanding public sector: A reexamination." Review of

[25] economics and statistics 70(2): 322-30.

[26] Constantinos Alexiou,Government spending and economic growth :Econometric evidence from the Southern Eastern

[27] Europe ,Journal of economics and social research 11(1) 2009,1-16.

[28] Daniel J.Agenor Pierre-Richard,Neanidis Kyriakos C(2006).The allocation of public expenditure and economic growth ,

[29] Economics Discussion Paper ,EDP-0608, March 
[30] Daniel J.Mitchel, The impact of government spending on economic growth .March 31,2005,No 1831.

[31] Epstein , $G$ and Gintis ,H( 1995).A dual-agency approach to state and market .In G .Epstein and

[32] H.Gintis(eds):Macroeconomic policy after the conservative era:Studies on investments ,savings and finance,

[33] pp 384-407 Cambridge,Cambridge university press

[34] Feder,G(1982). On exposits and economic growth .Journal of development economics 12:59-73

[35] Folster .S and M.Henrekson (1999) . Growth and the public sector "A critique of the critics".Europian journal of political

[36] economy 15(2):337-358

[37] Folster .S and M.Henrekson (2001). Growth effects of governments expenditures and taxation in rich

[38] countries. Europian EConomic Review 48(8):1501-1520

[39] Gaston JEze, The sources of the receipts of the french government in 1920.

[40] Ghura ,D(1995) .Macro policies, external forces and economic growth in Sub-Saharian Africa.economic development

[41] and cultural change 43(4) _759-78

[42] Grier ,K.B and G.Tullock (1989).An empirical analysis of cross-national economic growth :1951-80.Journal of monetary

[43] economics 24(2):259-76

[44] Grossman,P.(1988). Growth in government and economic growth :the Australian experience.Australian economics

[45] papers 27:33-45

[46] Guseh J.S (1997).Government size and the economic growth in developing countries :A political-economy

[47] framework.Journal of macroeconomics 19(1):175-192

[48] Jong-Wha ,L (1995).Capital goods imports and long-run growth.Journal of development economics 48(1):91-110

[49] Kelly ,T.(1997).Public expenditures and growth .Journal of develoment studies 34:60-84

[50] Knoop,T.A.(1999). Growth, welfare and the size of government .Journal of economic inquiry. 37(1):103119

[51] Irmen Andreas, Kuehnel Johanna (2008), Productive government expenditure and economic growth, CESIFO working

[52] paper NO. 2314, May

[53] Jamee K.Moudud ,Government spending in a growing economy ,the Jerome Levy Economics Institute of Bard

[54] College,No 52A , July 1999.

[55] James S. Guseh, Government Size and Economic Growth in Developing Countries: A Political-Economy Framework,"

[56] Journal of Macroeconomics, Vol. 19, No. 1 (Winter 1997), pp. 175-192.

[57] Jong-Wha Lee, . Capital goods imports and long-run growth," Journal of development economics, Vol. 48, No. 1

[58] (October 1995), pp. 91-110.

[59] Koeda Junko, Kramarenko Vitali (2008), Impact of government expenditure on growth: The case of Azerbaijan, IMF 
[60] Working Paper, WP/08/115, May

[61] Macro Economy Meter, www.mecometer.com

[62] Ministry of Finance www.minfin.gov.al

[63] Nkiru Patricia ,Daniel Izuchukwu ,Impact of government expenditure on economic growth in Nigeria ,International journal

[64] of business and management review, Vol 1 ,No 4,pp 64-71, december 2013.

[65] P. Hansson and M. Henrekson, A new framework for testing the effect of government spending on growth and

[66] productivity," public choice, Vol. 81 (1994), pp. 381-401.

[67] Roubini .N and Sala-I-Martin ,X.(1991). Financial development, the trade regime ,adn the economic growth. Cambridge:

[68] NBER , working paper , no 3876.

[69] S. M. Miller and F. S. Russek, Fiscal structures and economic growth at the state and local level," Public finance

[70] review, Vol. 25, No. 2 (March 1997).

[71] .Thomas Statman and Gabriel Okolski ,Does government spending affect economic growth ,Mercatus Center , George

[72] Mason University ,No 76 , June 2010.

[73] Vilay L.N Gangal and Ms.Honey Gupta,Public expenditure and economic growth ,A case study of India ,Global Journal of

[74] Management and Business studies ,Volume 3,Number 2(2013),pp 191-196.

\section{Graphes}

Graph 1 :Albania government expenditures from 1991-2012

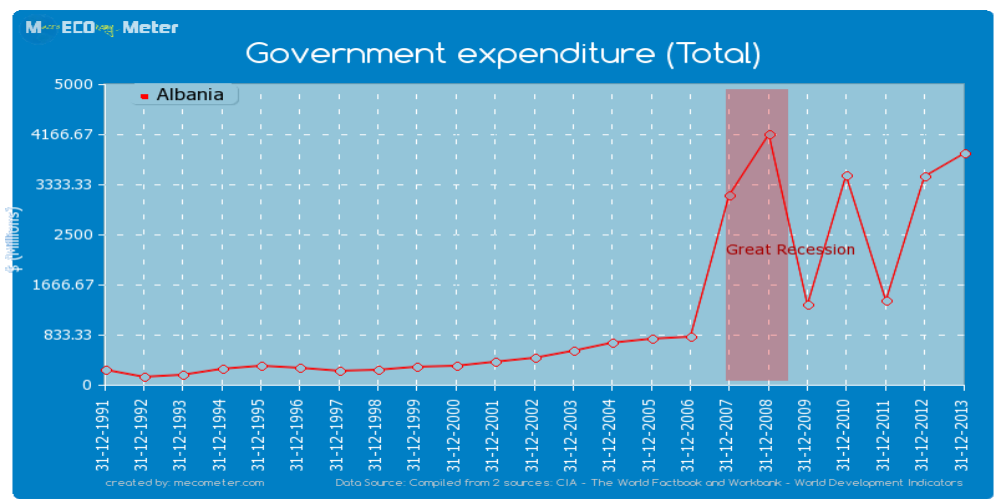

\section{Source :Mecometer}

Graph 2 :Albania Government expenditures from 1991-2012

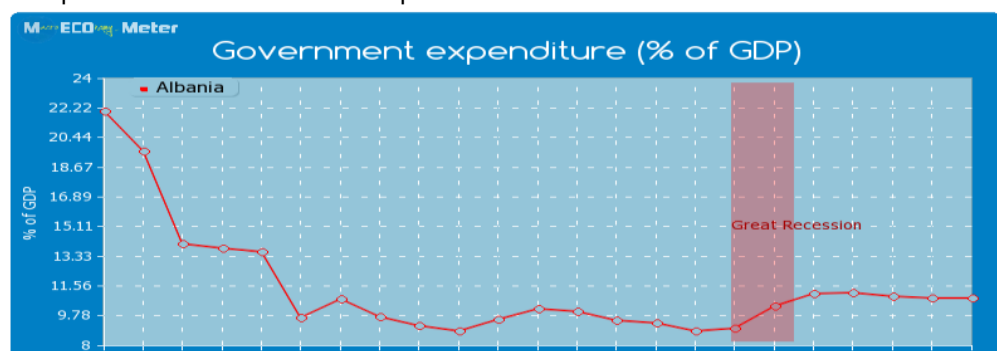




\section{Source:Mecometer}

Graph 3 :Albania Government expenditures structure from 1991-2012

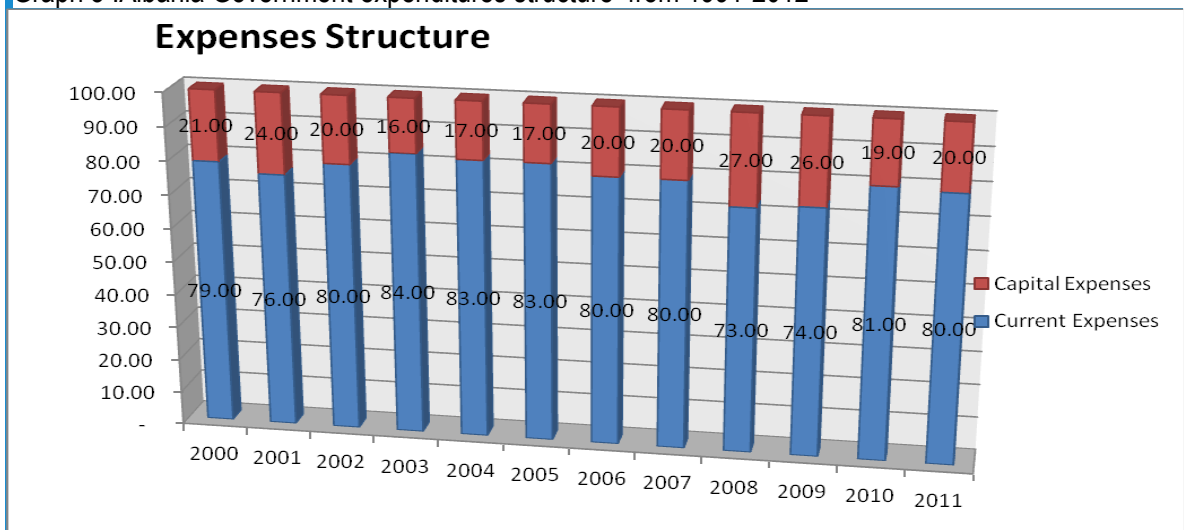

Source :Mlnistry of Finance

Graph 4 :Capital expenditures Albania

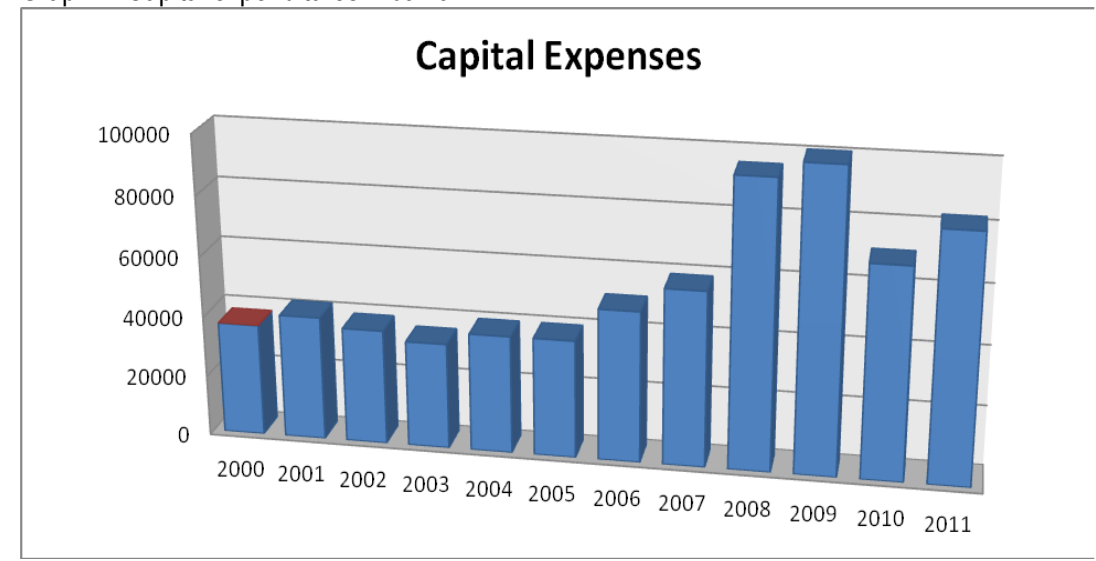

Source :Ministry of Finance 
Graph 5: Financing structure investments in Albania

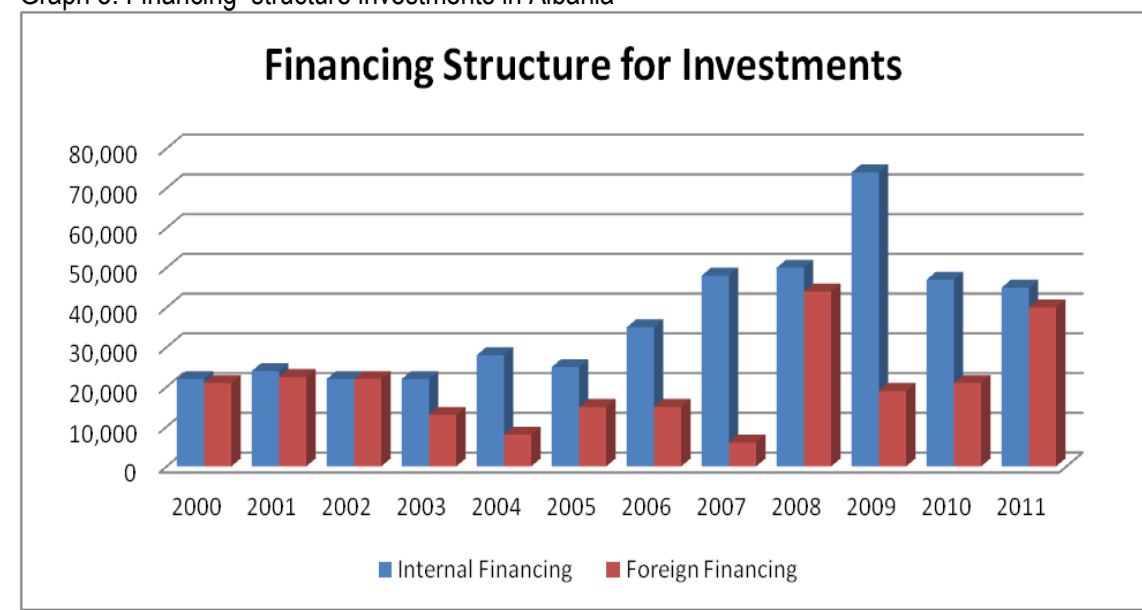

Source :Ministry of Finance.

Graph 6: Allocation of budget expenditures for 2012 by functions.

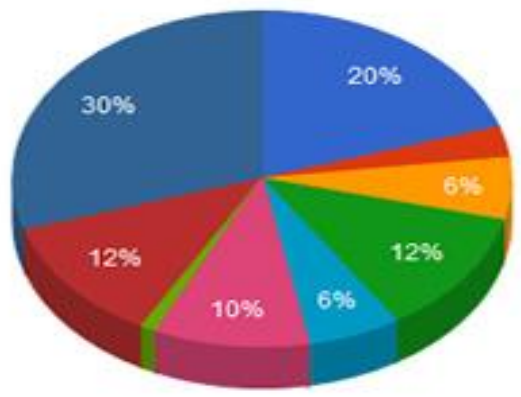

Source :Ministry of Finance

As can be seen from graph 7 social protection is $30 \%$; General public services $20 \%$; education $12 \%$; economic issues $12 \%$; Health $10 \%$; housing and community amenities $6 \%$; public order and safety $6 \%$; protection $3 \%$; recreation, culture and religious affairs $1 \%$

Graph 7: Budgetary Expenditures Albania Compared with countries Region

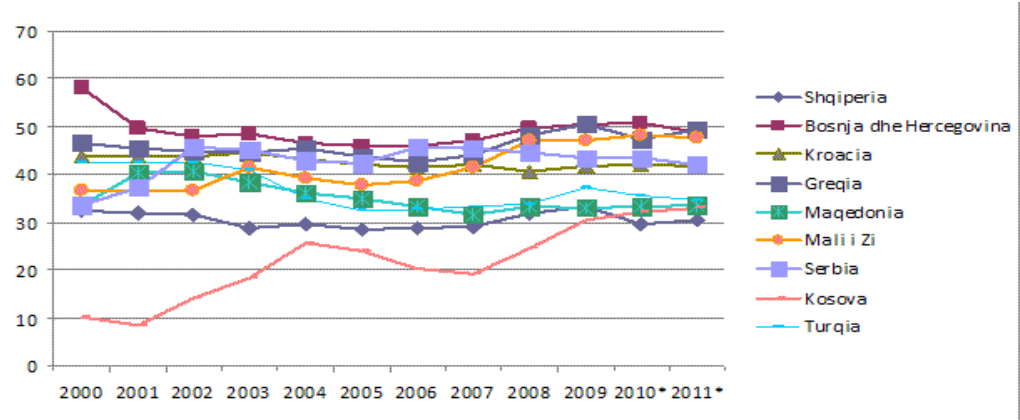

Source:IMF 
ISSN 2411-9563 (Print)

ISSN 2312-8429 (Online)
European Journal of Social Sciences Education and Research
September-December 2014

Volume 1, Issue 2

\section{Graph 8 :Economic growth in Albania}

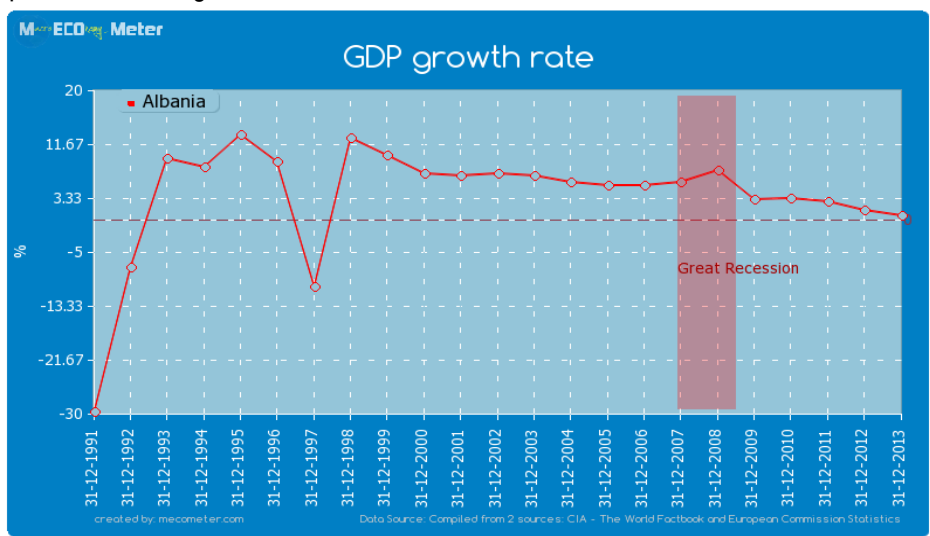

Source:Mecometer. 